\title{
Community Empowerment Based On Social Entrepreneurship Training: Training In Management Of Coffee Leather Brownies Business In Soppeng City, South Sulawesi
}

\author{
Nur Amin MT ${ }^{1}$, Tingga Sari Novi Prakaswati ${ }^{2}$, Husnul Khotimah ${ }^{3}$, Iin Sumarto ${ }^{4}$ \\ 1,2, 3,4 Economic Education, Universitas Pendidikan Indonesia, Bandung \\ $1^{\text {st }}$ nuraminmt@upi.edu 2 ${ }^{\text {nd }}$ tinggasari28@gmail.com \\ $3^{\text {rd }}$ husnulkhotimah@upi.edu4th37iinsumarto@upi.edu
}

\begin{abstract}
The purpose of this study was to determine the level of success of the implementation of social entrepreneurship-based community empowerment programs in the training of business management of coffee skin brownies in Soppeng City, South Sulawesi. The population of this study was all people who participated in entrepreneurship training in the community empowerment program as many as 285 people. Data was collected using a questionnaire instrument that was processed and analyzed using quantitative descriptive analysis. The results showed that the level of success of the implementation of social entrepreneurship training-based empowerment programs in Soppeng City was highly measured by indicators: (1) increased knowledge and skills of the community in managing coffee skin into brownies, preparing business/business plans, and making simple books; (2) increasing community participation in training programs; and (3) increasing interest in the community in developing social-based creative entrepreneurship.
\end{abstract}

Keyword: Community Empowerment, Entrepreneurship Training, Social Entrepreneurship

\section{INTRODUCTION}

Social entrepreneurship based on an entrepreneurial approach becomes the idea of social change that arises amid social change and social problems in society. The phenomenon of social entrepreneurship is growing rapidly along with efforts to resolve various social problems, such as improving the economy and social welfare of the community. Supporting this opinion, a study conducted by Perrini and Vurro which analyzed the theory and practice of social entrepreneurship found that the application of the social entrepreneurship model had an impact on the social welfare of the community. This finding is also relevant to the opinion of Utomo, that social entrepreneurship that grows very rapidly can overcome social problems.

Social entrepreneurship is commonly called "community development" or social purpose organizations". Furthermore, this form of social entrepreneurship, such as community-based organizations, socially responsible enterprises, socio-economic or dualistic enterprises and community empowerment. Social entrepreneurship sees problems as an opportunity to form a new business model that is beneficial for 
empowering the surrounding community. ${ }^{1}$ Furthermore, Hibbert, Hogg, and Quinn explain that social entrepreneurship as the utilization of entrepreneurial behaviour is more oriented towards achieving social goals and does not prioritize profitability or the profits obtained are used for social purposes. ${ }^{2}$

The development of developing social entrepreneurship is usually carried out through community empowerment programs, in accordance with social phenomena or social problems faced by the community. Relevant to the concept of social entrepreneurship, Zunadi suggests that community empowerment is a process that builds people or society through developing community potential, changing community behaviour, and organizing the community. This understanding provides an understanding that community empowerment is an effort to enable and empower the community to improve their standard of living in conditions of underdevelopment and limited ability to escape from poverty. ${ }^{3}$

In this study, a community empowerment program was conducted in Soppeng City, South Sulawesi. Soppeng City is known to have abundant agricultural potential, namely coffee. However, this commodity has not been well optimized, especially in Lalabata District, Soppeng Regency. The lack of understanding and skills of the community is an obstacle in maximizing processed coffee products so that the selling value is still relatively low. In addition, the community generally does not participate in any training programs carried out by the government. Therefore, with the existence of a community empowerment program, it is hoped that it can be a solution to help the development problems in Lalabata Sub-District, Soppeng City

Coffee is one of the potential of community agriculture in Lalabata Subdistrict, Soppeng City, as well as a superior commodity. However, coffee farmers only sell raw coffee beans to collectors at relatively low prices from processed coffee. Even though some people, especially housewives, process coffee ready for consumption, true marketing and business management have not been implemented. In addition, only coffee beans are utilized, while coffee skin is not processed so it becomes waste around the house.

1 Wee-Ling Tan, John Williams, dan Teck-Meng Tan, "Defining the 'Sosial' in 'Sosial Entrepreneurship': Altruism and Entrepreneurship" International Entrepreneurship and Management Journal 1, (Italy: abacademies Journal, 2005). pp 353-365.

${ }^{2}$ A. S. Hogg Hibbert \& T. Quinn, "Social Entrepreneurship: Understanding Consumer Motives for Buying The Big Issue”. Journal of Consumer Behaviour. Vol. 4, 3, (Australia: Melbourne, 2005), hal;. 159-172. https://doi.org/10.1002/cb.6

${ }^{3}$ M. Zunadi, Community empowerment (Jakarta: Bumi Aksara, 2010), hal. 45. 
It can be seen that in general, the community does not have innovation in processing coffee into a more valuable product, lack of bookkeeping / financial reports and even lack of business planning so that the coffee business does not experience development. This indicates that the coffee business involved in the community has not been managed professionally. In addition, the main problem that occurs is the lack of community participation in household business activities, as well as the loss of togetherness in working together in the community because most people spend more time relaxing at home after finishing gardening.

Based on these problems, this social entrepreneur-based community empowerment program will help the community to develop its coffee business with product innovation so as to increase its selling value. The existence of market demand for coffee ready for consumption and innovation of coffee leather products provides an opportunity to develop a coffee processing business. Thus, it is necessary to formulate a business plan for the development of a coffee processing business (business plan). Business plans consist of short-term planning (in the form of work plans, budget plans, and expenditure revenues) and long-term plans for new business plans, existing business development, and existing business rehabilitation using business feasibility studies. Therefore, to develop its business, the owner also needs to develop a business plan.

Efforts to solve these problems have been implemented through community empowerment programs through training using an entrepreneurial approach based on social or social entrepreneurship. Training in Soppeng City's Lalabata District includes; (1) Training on processing coffee skin into Brownies cakes, (2) Training on processing coffee beans into ready-to-consume coffee with packaging designs, (3) Training on business planning preparation, and (4) Training on simple bookkeeping or preparation. As a measure of the success of this social entrepreneurship based empowerment program, it is necessary to conduct an evaluation in the form of research. The objectives of this study are: (1) to find out the participation of the community in social entrepreneurship-based empowerment programs, (2) to find out the level of understanding and skills of the community in processing coffee businesses into innovative and quality products, and (3) to identify community interest in develop social-based creative entrepreneurship.

\section{LITERATURE REVIEW}

\section{Community Empowerment Concept}


Empowerment is an active and participatory process in which individuals and groups gain greater control over their lives, gain rights, and reduce marginalization. ${ }^{4}$ Furthermore, empowerment is understood as an effort to help someone or a group of people by helping themselves through developing abilities that can later be empowered to improve their standard of living. Supporting this opinion, Sikhondze suggests that the orientation of community empowerment must help the community to be able to develop themselves on the basis of existing innovations, determined in a participatory manner, through a method approach oriented to the needs of the target community and practical matters. both in the form of individual and group services. ${ }^{5}$

Wrihatnolo argues that community empowerment contains two meanings, namely: (1) giving power, diverting power or delegating authority to other parties; and (2) efforts to provide capacity or empowerment. The other party in question is a person or group of people. Empowerment is a holistic process, namely an active process between motivators, facilitators and community groups that need to be empowered through increasing knowledge, skills, providing various facilities, as well as opportunities to achieve access to resource systems in improving community welfare. Furthermore, according to Bhinadi steps are needed to strengthen institutions, both village social institutions, and functional institutions, economic institutions in the village. Healthy and strong institutions are the main capital in developing human resources because through institutional processes, community empowerment will be more effective. ${ }^{6}$

The community empowerment intended in this study is the empowerment of the informal sector, especially farmers and housewives, young women/men or youth groups as part of the community who need their own guidance from the government. As an effort to improve the quality of their potential, where the target will be to increase their income so as to be able to contribute to regional revenue from the regional levies sector.

\section{The Purpose of Community Empowerment}

The purpose of community empowerment, namely the empowered community, has the power or knowledge and ability to fulfil their life needs both physically, economically, and socially. This explanation means that the purpose of community

${ }^{4}$ K. I. Maton, "Empowering community settings: Agents of individual development, community betterment, and positive social change". American Journal of Community Psychology, 41, (Amerika: Wiley, 2008). Pp 4-21. doi:10.1007/s10464-007-9148-6

5 Wilson B. Sikhondze, "The Role of Extension in Farmer Education and Information Dissemination in Swaziland". Journal: Adult Education and Development No. 53/1999, Institute for International Cooperation of The German Adult Education Association, Bonn : 112/DW (German: ....., 1999), hal. 36.

${ }^{6}$ Ardito Bhinadi, “Poverty Reduction and Community Empowerment”. (Yogyakarta: Deepublish, 2017), hal. 69.

Website:http://jurnal.radenfatah.ac.id/index.php/ieconomics 
empowerment emphasizes the formation of individuals and the community becomes more independent and empowered. Independence referred to is the independence of thinking, acting, and controlling oneself. ${ }^{7}$

The purpose of community empowerment is defined as the formation of an independent society. As stated by Steinberg that the independence of the community is the ability of the community to carry out an account for the actions they take, and to establish supportive relationships with other communities. Furthermore, the goal of community empowerment should lead to the formation of a better cognitive, conative, effective, and psychomotor society. ${ }^{8}$

The cognitive formation is more directed at improving thinking skills based on the knowledge and insight of someone in finding solutions to problems faced in social life. Conative formation emphasizes the formation of attitudes and behaviour of people who are sensitive to the values of development and empowerment. Affective formation emphasizes increasing community sensitivity which is expected to be intervened to achieve empowerment in attitudes and behaviour. While psychomotor formation places more emphasis on life skills improvement that is owned by the community as a supporter in increasing economic and social activities so as to increase income and standard of living.

Based on the description, it can be stated and understood that the purpose of community empowerment in this study, namely; (1) increasing community participation in empowerment programs, (2) increasing community knowledge, understanding and skills, and (3) increasing public awareness for independence.

\section{Stages of Community Empowerment}

The community empowerment program has several stages leading to a better level. The stages of community empowerment can be seen through the following scheme: ${ }^{9}$

1. Stages of Management (Engagement)

At this stage, it is carried out through the preparation stage of the officer and preparation of the field.

\footnotetext{
${ }^{7}$ E. Suharto, “Building a Community Empowering People” (Bandung: PT. Rafika Aditama. 2005), hal. 28.

${ }^{8}$ L. Steinberg, “Adolescence” (New York: McGraw Hill Companies, Inc. 2002), hal. 23.

9 Isbandi Rukminto Adi, “Community Intervention: Community Development as an Effort for Community Empowerment” (Jakarta: Rajawali Pers, 2013), hal. 33.
} 
a. Preparation of officers is the preparation of community empowerment staff. This stage can be done by part of the community itself.

b. Field preparation. At this stage, the officer initially conducts a feasibility study on the areas to be targeted for empowerment.

2. Assessment Phase

At this stage identification of problems related to perceived needs or needs and conditions of the community is carried out.

3. Planning or Alternative Program (Design) Alternative Stage

At this stage, what needs to be done is to try to involve citizens to think about the problems faced and how to overcome them.

4. Stage of Formulating Action Plan (Formulation)

At this stage, the change agent helps the community to formulate and determine the programs and activities they will carry out in overcoming existing problems to achieve short-term and long-term goals.

5. Stage of Program or Activity Implementation (Implementation)

This stage is one of the most important stages in the process of community empowerment. The role of the community as executors of community empowerment programs is expected to be able to maintain the sustainability of the programs that have been developed.

6. Evaluation Phase

Evaluation as a process of monitoring citizens and officers towards ongoing community empowerment programs should be carried out by involving the community.

7. Phase Termination

This stage is the formal phase of the termination of the relationship.

\section{Social Entrepreneurship Concept}

According to Bill Drayton as the initiator of social entrepreneurship, there are two key things in social entrepreneurship. First, there are social innovations that are able to change the system in society. Second, the presence of visionary, creative, entrepreneurial, and ethical individuals behind these innovative ideas. ${ }^{10}$ In addition, social entrepreneurship is seen as an entrepreneur who enhances the welfare of marginalized groups and vulnerable groups. Furthermore, social entrepreneurship is an

10 R. Rahadi dan Susilowaty, "Creativity on Social Entrepreneurship and Exploring New Business Ideas through Processing Tempe Lupine Chips". Jurnal Pengabdian dan Kewirausahaan, Vo. 1, No. 1, (k: Penerbit, 2018). hal 17-24.

Website:http://jurnal.radenfatah.ac.id/index.php/ieconomics 
entrepreneurial process that focuses on forming social values or norms against other people and groups. ${ }^{11}$

Social entrepreneurship is different from entrepreneurship in general, which only focuses on finding as much profit as possible. This concept is not only aimed at looking for profit but also to reduce the unsustainability of the results obtained from the entrepreneurial process, especially in the social aspect. Social entrepreneurship is also seeking profit, but it is not the main goal. Changing people's mindsets and other social agendas are the main goal compared to economic benefits.

Social entrepreneurship according to Martin \& Osberg, has several definitions, namely: ${ }^{12}$

1. Identify the factors that cause unstable economic conditions that have an impact on the occurrence of marginalization or suffering for groups that do not have good financial conditions or political strength.

2. Identify opportunities in unstable economic conditions, develop social values, and encourage people to create innovation, creativity, real action, and courage in dealing with these conditions.

3. Encourage stable new economic conditions to release groups of people from poverty and suffering due to unstable economic conditions. This can also encourage better conditions in the future, not only in the target group but also in society at large.

The main trigger of social entrepreneurship activities is the actual social problem that is being handled, where organizations make decisions in resource management based on the most effective format needed to overcome the problem. In theory, the definition of social entrepreneurship is still a debate. The definition of social entrepreneurship is divided into two groups, 1) the definition of broad social entrepreneurship, 2) the definition of entrepreneurship specifically. The definition of social entrepreneurship as an implementation of entrepreneurship which has a social impact, whatever the form of organization in practice is more widely accepted.

The concept of social entrepreneurship also has different meanings for various practitioners and researchers. The differences in the definition of social entrepreneurship (social entrepreneurship), social entrepreneurs (social entrepreneurs),

11 K. Schaefer, Corner \& Kearins, "Social, Environment and Sustainable Entrepreneurship Research: What Is Needed for Sustainability-as-Flourishing”. Journal Organization and Environment, Vol. 28, No. 4, (k: Penerbit, 2015), pp. 394-413 DOI: $10.1177 / 1086026615621111$.

${ }^{12}$ L. R Martin \& Sally Osberg, "Social Entrepreneurship: The Case for Definition". Stanford Social Innovation Review, Spring, 2007, hal. 30-39.

Website:http://jurnal.radenfatah.ac.id/index.php/ieconomics 
and social enterprises (social enterprise) are summarized by (Mair and Marti, 2004). ${ }^{13}$ Social entrepreneurship is initiated at the individual level, social enterprises begin in organizational movements that apply market-based strategies to achieve social change. ${ }^{14}$ In other words, the universally accepted equation for the definition of social entrepreneurship is the fact that the underlying trigger is the goal of creating social value rather than the welfare of individuals or shareholders. ${ }^{15}$

In general, explained by Hulgard social entrepreneurship is social value creation resulting from collaboration with other people and organizations from the community who are involved in the creation of social innovations in economic activities; so from this definition, there are four criteria of social entrepreneurship. The four criteria are social value, community environment, innovation, and economic activities. ${ }^{16}$

The comprehensive definition above gives an understanding that social entrepreneurship consists of four main elements, namely social value, civil society, innovation, and economic activity.

1. Social Value. This is the most distinctive element of social entrepreneurship, which is creating real social benefits for the community and the surrounding environment.

2. Civil Society. Social entrepreneurship generally comes from the initiative and participation of civil society by optimizing social capital in the community.

3. Innovation. Social entrepreneurship solves social problems in innovative ways, among others by combining local wisdom and social innovation.

4. Economic Activity. Successful social entrepreneurship in general by balancing social activities and business activities. Business / economic activities are developed to guarantee the independence and sustainability of the organization's social mission.

\section{Social Entrepreneurship Component}

Social entrepreneurship consists of three main components, namely (1) the entrepreneurial context (the entrepreneurial context), (2) entrepreneurial characteristics (the entrepreneurial characteristics), and (3) entrepreneurial outcomes. This component

${ }^{13}$ J. Mair, \& I. Marti, "Social Entrepreneurship Research: A Source of Explanation, Prediction, and Delight". Journal of World Business, Volume 41, Issue 1, 2004. 36-44. https://doi.org/10.1016/j.jwb.2005.09.002

${ }^{14}$ I Popoviviu \& A. S. Popoviciu, Social Entrepreneurship, Social Enterprise and the Principle of A Community of Practive. Journal Review of Research and Social Intervention, vol. 33, 2011, pp. 44 -55 ,

${ }^{15}$ R. M. Noruzi, Westover \& R. G. Rahimi, An Exploration of Social Entrepreneurship in The Entrepreneurship Era. Journal Asian Social Science, vol. 6, No. 6, 2010, pp. 3-10.

16 L. Hulgard, "Discourse of Social Entrepreneurship - Variations of The Same Theme". European Research Network, 2010, pp 1-21.

Website:http://jurnal.radenfatah.ac.id/index.php/ieconomics 
is a guide for social entrepreneurs to plan and implement their ideas in the context of social entrepreneurship. ${ }^{17}$

The entrepreneurial context shows the identification of social factors that determine and extend poverty, marginalization, and exclusion. The characteristics of entrepreneurship refer to direct actions in the form of new solutions or innovations for the target population (target population), context, or application. The third component; the results of social entrepreneurship, referring to stable new ecosystems or substantial social changes to the segment (target) of the disadvantaged population. The results of social entrepreneurship are visible and measurable through improved quality of life, efficiency, social sustainability and or valuable economic growth options. Assert that social change can be small scale (usually covering small or local areas) or large scale (systemic or changes that are more related to a system). Thus, the results of social entrepreneurship can be directly beneficial to the target population within a particular region or the results can be either a shift or a change of paradigm. ${ }^{18}$

\section{Characteristics of Social Entrepreneurship}

Social entrepreneurs have characteristics that also refer to the application of leadership. Some characteristics of social entrepreneurs include: ${ }^{19}$

1. People who have the vision to solve social problems as community reformers with very strong ideas or ideas to improve people's lives.

2. People who have transformative power, namely those who apply new ideas in the face of big problems, who are relentless in realizing their mission, like challenges, have high endurance, never give up until they succeed in spreading their ideas as far as they can.

3. People who are able to change the power of community performance by continually improving, strengthening and expanding their ideas.

4. People who advance systemic change: how they can change patterns of behaviour and a particular understanding of social and environmental issues.

\section{RESEARCH METHODS}

This type of research is quantitative descriptive research. This study illustrates the success rate of social entrepreneurship-based community empowerment programs in

${ }^{17}$ L. R. Martin, \& Sally Osberg, "Social Entrepreneurship: The Case for Definition", Stanford Social Innovation Review, (Stanford: Spring, 2007), hal. 30-39

${ }^{18}$ Ibid. Hal. 40.

${ }^{19}$ D. Borstein, How to change the world: Socio entrepreneurs and the power of new ideas, (New York: Oxford University Press, 2006), hal. 54. 
Lalabata District, Soppeng Regency. The population in this study were all training participants in Lalabata District, Soppeng Regency. The sample of this study was drawn by purposive sampling. Thus, the sample in this study is the people who have participated in training with the approach to social entrepreneurship in the community empowerment program, as many as 285 people including; training programs for processing coffee beans and coffee skin into brownies as many as 90 people, a business plan preparation training program as many as 85 people, and a simple bookkeeping making training program of 110 people. In this study, no sampling was conducted because at the end of each training data collection was carried out to all participants through the questionnaire instrument. Data that has been collected, processed and analyzed using quantitative descriptive analysis.

\section{RESEARCH RESULT}

To find out the success of the implementation of community empowerment based on the type of social-based entrepreneurship training in Lalabata Subdistrict, Soppeng City, can be seen in Table 1 below.

Table 1.

The Success Rate of Implementation of the Community Empowerment Program Based on the Type of Social Based Entrepreneurship Training.

\begin{tabular}{clccccc}
\hline \multirow{2}{*}{ Number } & $\begin{array}{l}\text { Entrepreneurship } \\
\text { Training Program }\end{array}$ & $\begin{array}{c}\text { Number of } \\
\text { Participants }\end{array}$ & Ideal Score & $\begin{array}{c}\text { Score } \\
\text { Acquisition }\end{array}$ & Total & Category \\
\cline { 4 - 6 } 1 & $\begin{array}{l}\text { Processing Coffee } \\
\text { Skin into Brownies } \\
\text { Cakes }\end{array}$ & 90 & 2700 & 2350 & 87,03 & Very High \\
2 & $\begin{array}{l}\text { Business Planning } \\
\text { Compilation }\end{array}$ & 85 & 2550 & 2210 & 86,66 & Very High \\
3 & $\begin{array}{l}\text { Simple } \\
\text { Bookkeeping }\end{array}$ & 110 & 3300 & 3100 & 93,93 & Very High \\
\hline \multicolumn{1}{c}{ Total } & 285 & 8550 & 7660 & 89,59 & Very High \\
\hline
\end{tabular}

Source: Data Processed (2019)

Table 1 shows that the success rate of implementing a community empowerment program with a social entrepreneurship approach based on the type of entrepreneurship training in the Soppeng City Lalabata District is very high including; (1) Training for processing coffee skin into Brownies Cake has a percentage of $87.3 \%$, (2) Training on business planning preparation with a percentage of $86.6 \%$, and (3) Training on simple bookkeeping with a percentage of $93.9 \%$.

Table 2

The Success Rate of Implementation of the Community Empowerment Program Based on Indicators of Participation, Knowledge and Skills of the Community in the District of Lalabata, Soppeng City.

\begin{tabular}{|c|c|c|c|c|c|c|}
\hline \multirow[b]{2}{*}{ Number } & \multirow[b]{2}{*}{$\begin{array}{l}\text { Entrepreneurship } \\
\text { Training Program }\end{array}$} & \multirow[b]{2}{*}{$\begin{array}{l}\text { Number of } \\
\text { Participants }\end{array}$} & \multicolumn{3}{|c|}{ Performance Score } & \multirow[b]{2}{*}{ Category } \\
\hline & & & Ideal Score & $\begin{array}{c}\text { Score } \\
\text { Acquisition }\end{array}$ & Total & \\
\hline
\end{tabular}


Community Empowerment Based on .... Nur Amin, Tingga Sari Novi Prakaswati, Husnul Khotimah, Iin Sumarto

\begin{tabular}{llccccc}
\hline 1 & $\begin{array}{l}\text { Processing Coffee } \\
\text { Skin into Brownies }\end{array}$ & 285 & 4275 & 3850 & 90,05 & Very High \\
$\begin{array}{l}\text { Cakes } \\
\text { Business Planning } \\
\text { Compilation }\end{array}$ & 285 & 2850 & 2420 & 84,91 & Very High \\
3 & $\begin{array}{l}\text { Simple Bookkeeping } \\
\quad \text { Average }\end{array}$ & 285 & 1425 & 1265 & 88,77 & Very High \\
\hline & 285 & 8550 & 7535 & 88,12 & Very High \\
\hline
\end{tabular}

Source: Data Processed (2019)

Table 2 shows that the level of success of community empowerment programs seen from the indicators of participation, knowledge and skills of the people in Lalabata Subdistrict, Soppeng City is in the very high category. These findings also indicate that the empowerment program using a social entrepreneurship approach is able to increase the interest of social entrepreneurship in the community.

Thus, it can be stated that the success rate of the community empowerment program implementation program is in the high category in terms of several indicators.

\section{Supporting and Inhibiting Factors}

The supporting factors in the implementation of the program are: (1) High community participation in program implementation, (2) Availability of raw materials needed for the program, (3) Availability of training equipment so as to facilitate the community in following training programs, (4) Availability of place of implementation so the program can run well, (5) There is government support so that the program runs well. Meanwhile, the inhibiting factors for program implementation include: (1) Communities find it difficult to convey and understand some information, and transfer technology because education levels are still low, (2) Raw materials are relatively expensive because they have not entered the harvest season.

\section{DISCUSSION}

\section{Level of Community Participation in the Community Empowerment-Based Community Empowerment Program}

The success of this social-based entrepreneurship training program is largely determined by the active participation of the community as very high entrepreneurship training participants seen from the indicators of attendance, discipline, activity and initiative of participants in participating in the training. This, as stated by Isbandi that participation is the participation of the community in the process of identifying problems and potential that exist in the community, selection and decision making about alternative solutions to address problems and community involvement in the development process. $^{20}$ The active participation of the community in the implementation of the program is very important as a measure of the ability of the community to take the initiative and enjoy the results of the development that has been done.

${ }^{20}$ Ibid. Adi, Isbandi Rukminto, Community Intervention: Community Development as an Effort for Community Empowerment, (Jakarta: Rajawali Pers, 2010), hal. 35. 
Social entrepreneurship-based community empowerment through training on coffee skin management into cakes Brownies aims to increase the income of people who are unable to escape the poverty line and underdevelopment. Therefore, increasing community participation in community empowerment programs must pay attention to the potential of the region that can be developed, strengthen the potential of the community, and increase community participation in program implementation.

\section{Level of Knowledge and Community Skills}

The level of knowledge and skills of the community in this social-based entrepreneurship training program was successfully achieved. Based on the results of the analysis of the data obtained from the training participants using a questionnaire instrument, indicating that the level of knowledge and skills of the trainees increased or were very high. This shows that the training participants have knowledge and skills based on indicators of material mastery and practical ability. This finding was also supported by the results of interviews with several training participants, namely increasing knowledge, skills, and practical abilities and changing attitudes to work and trying to be independent, creativity to take advantage of the business opportunities they have.

The results of this study are relevant to the findings of Sanchez which shows that entrepreneurship training increases the competency, interest, and entrepreneurial behaviour of participants. This finding is seen from the participant's proactive indicators, participants 'interests, and participants' attention to the entrepreneurship given. $^{21}$

These empowerment targets are prioritized for unemployed or non-permanent people and less developed small-scale shop owners. Through this social entrepreneurship training program, the community is expected to be able to be independent in working through quality coffee and coffee skin production efforts and continue to prioritize the social interests of the community.

The results of community empowerment are aimed at increasing people's knowledge and skills in managing their business in accordance with their regional potential. With these competencies, the community can open their own employment opportunities and for others so that they can increase their income. Thus, independence is the ultimate goal achieved after the implementation of the training program.

\section{Level of Community Interest in Developing Social Business Groups}

The implementation of this empowerment program has increased public awareness to develop social entrepreneurship. This can be seen from the indicators that there are some people who have given up their training programs to open businesses at home such as receiving ready-made coffee and flavoured Brownies cakes.

${ }^{21}$ C. J. Sanchez, "University Training for Entrepreneurial Competencies: Its Impact on Intention of Venture Creation" International Entreprenurship and Management Journal. Volume 7, Issue 2, 2011. pp 239-254. DOI https://doi.org/10.1007/s11365-010-0156-X 
Based on the results of data analysis, it was shown that some housewives who had participated in social-based entrepreneurship training benefited, such as; (1) the existence of knowledge and skills in processing coffee beans and skin into brownies so that they try to open a business at home, (2) Efforts to accept coffee and cake orders for coffee skin brownies have increased family income.

These findings are relevant to the results of Farashah study, which shows that entrepreneurship training increases the interest in entrepreneurship, increasing the desire for an entrepreneurial career, and fostering community independence for entrepreneurship. ${ }^{22}$ Training also contributes to increasing interest, skills and motivation for entrepreneurship. The same finding by Sanchez, who found that entrepreneurship training was able to improve the competency and interest of participants in entrepreneurship. ${ }^{23}$

\section{CONCLUSION}

\section{Conclusion}

Based on the results of the implementation of the community empowerment program based on social entrepreneurship training in the District of Lalabata, Soppeng City, it can be summarized as follows.

1. Community participation increases in participating in community empowerment programs based on social entrepreneurship training.

2. Knowledge and skills of the community are increasing in producing coffee and coffee skin in the form of quality brownies cakes and high selling value.

3. Knowledge and understanding of the community increases in making / compiling business plans, and arranging simple books.

4. Community awareness and interest increases in developing social-based entrepreneurship by utilizing regional potential.

\section{Suggestion}

The suggestions that can be stated in relation to the conclusion of the implementation of this program are:

1. Community participation in empowerment activities must be maintained so that empowerment activities are carried out properly in the context of development in Lalabata District, Soppeng City.

2. The government should conduct local potential based training to the community to support the sustainability of the programs that have been implemented.

${ }^{22}$ A. D. Farashah, The Process of Impact of Entrepreneurship Education and Training on Entrepreneurship Perception and Intention (Study of Educational System of Iran). Journal Education + Training, Vol 55 No. 8/9, 2013, DOI 10.1108/ET-04-2013-0053.

${ }^{23}$ J. Sugiarto, Wismanto \& Utami, Effectiveness of Entrepreneurship Skill Training to Increase Interest in Becoming an Entrepreneur. Jurnal Ilmiah Magister Psikologi. Vol. 2, No. 1, 2015, hal. 5160 . 
3. People who have participated in the training program are expected to be able to transfer their knowledge and skills to other communities.

4. It is expected that there will be assisted by the government to the community or small business groups/household businesses so that the business can grow and develop in order to improve the standard of living of the people in Lalabata SubDistrict, Soppeng City.

\section{REFERENCE}

\section{A. Book}

Adi, Isbandi Rukminto. 2013. Community Intervention: Community Development as an Effort for Community Empowerment. Jakarta: Rajawali Pers

Bhinadi, Ardito. 2017. Poverty Reduction and Community Empowerment. Yogyakarta: Deepublish

Borstein, D. (2006). How to change the world: Socio entrepreneurs and the power of new ideas. New York: Oxford University Press.

Dwidjowijoto dan Wrihatnolo. 2007. Empowerment Management: An Introduction and Guide to Community Empowerment. Jakarta: PT. Elex Media Komputindo.

Isbandi, Rukminto Adi. 2007. Community Asset-Based Participatory Planning: From Thought to Application. Depok: Fisip UI press.

Zunadi, M. 2010. Community empowerment. Jakarta: Bumi Aksara.

\section{B. Journal}

Farashah, A. D. 2013. The Process of Impact of Entrepreneurship Education and Training on Entrepreneurship Perception and Intention (Study of Educational System of Iran). Journal Education + Training, Vol 55 No. 8/9, DOI 10.1108/ET04-2013-0053.

Hibbert, A. S., Hogg, G., \& Quinn, T. 2005. Social Entrepreneurship: Understanding Consumer Motives for Buying The Big Issue. Journal of Consumer Behaviour. Vol. 4, 3, 159-172. https://doi.org/10.1002/cb.6

Hulgard, L. 2010. Discourse of Social Entrepreneurship - Variations of The Same Theme?. European Research Network, pp 1-21.

Perrini, F., dan C. Vurro, 2006. Social Entrepreneurship: Innovation and Social Change Across Theory and Practice. Dalam. J. Mair, J. Robinson, dan K. Hockerts (Ed.). Social Entrepreneurship: 57-85. New York (USA): Palgrave Macmillan.

Popoviviu, I \& Popoviciu, A. S. 2011. Social Entrepreneurship, Social Enterprise and the Principle of A Community of Practive. Journal Review of Research and Social Intervention, vol. 33, pp. $44-55$, 
Mair, J., \& Marti, I. 2004. Social Entrepreneurship Research: A Source of Explanation, Prediction, and Delight. Journal of World Business, Volume 41, Issue 1, Pages 3644. https://doi.org/10.1016/j.jwb.2005.09.002

Martin, L. R \& Sally Osberg. 2007. Social Entrepreneurship: The Case for Definition. Stanford Social Innovation Review, Spring, 2007 hal. 30-39

Maton, K. I. (2008). Empowering community settings: Agents of individual development, community betterment, and positive social change. American Journal of Community Psychology, 41, 4-21. doi:10.1007/s10464-007-9148-6

Noruzi, R. M., Westover, H. J., \& Rahimi, R. G. 2010. An Exploration of Social Entrepreneurship in The Entrepreneurship Era. Journal Asian Social Science, vol. 6, No. 6, pp. 3-10.

Rahadi, R. D., dan Susilowaty, E. 2018. Creativity on Social Entrepreneurship and Exploring New Business Ideas through Processing Tempe Lupine Chips. Jurnal Pengabdian dan Kewirausahaan, Vo. 1, No. 1, hal 17-24.

Rappaport, J. (1981). In praise of paradox: A social policy of empowerment over prevention. American Journal of Community Psychology, 9, 1-25. doi:10.1007/BF00919275

Retno, S. S., Rohmayati, Y., dan Husna, J. 2015. Community Empowerment Through Libraries: A Case Study in Smart Houses "Sasana Ngudi Kawruh" BandarharjoSemarang Village. Journal Ilmu Perpustakaan, Vol. 4, No. 2, hal. 1-10.

Sanchez, C. J. 2011. University Training for Entrepreneurial Competencies: Its Impact on Intention of Venture Creation. International Entreprenurship and Management Journal. Volume 7, Issue 2, pp 239-254. DOI https://doi.org/10.1007/s11365-0100156-X

Schaefer, K., Corner, D. P., \& Kearins, K. 2015. Social, Environment and Sustainable Entrepreneurship Research: What Is Needed for Sustainability-as-Flourishing?. Journal Organization and Environment, Vol. 28, No. 4, pp. 394-413 DOI: $10.1177 / 1086026615621111$

Sikhondze, Wilson B. 1999. "The Role of Extension in Farmer Education and Information Dissemination in Swaziland". Journal: Adult Education and Development No. 53/1999, Institute for International Cooperation of The German Adult Education Association, Bonn : 112/DW.

Steinberg, L. 2002. Adolescence. New York: McGraw Hill Companies, Inc.

Sugiarto, J., Wismanto B. Y., \& Utami, T. C. 2015. Effectiveness of Entrepreneurship Skill Training to Increase Interest in Becoming an Entrepreneur. Jurnal Ilmiah Magister Psikologi. Vol. 2, No. 1, Hal. 51-60.

Suharto, E. 2005. Building a Community Empowering People. Bandung: PT. Rafika Aditama. 
Tan, Wee-Ling., Williams, John., dan Tan, Teck-Meng. (2005). 'Defining the 'Sosial' in 'Sosial Entrepreneurship': Altruism and Entrepreneurship'. International Entrepreneurship and Management Journal 1, pp 353-365.

Utomo, H., 2014. Growing Interest in Social Entrepreneurship. Among Makarti, 7(14): $1-16$.

Yuwono, S dan Partini. 2008. The Influence of Entrepreneurship Training on the Growing Interest in Entrepreneurship. Jurnal Penelitian Humaniora, Vol. 9, No. 2, P. 119-127.

Website:http://jurnal.radenfatah.ac.id/index.php/ieconomics 